\title{
EFIKASI DIRI DAN DUKUNGAN SOSIAL DOSEN PEMBIMBING SKRIPSI PADA PROKRASTINASI AKADEMIK MAHASISWA UNIVERSITAS UDAYANA
}

\author{
Ni Nyoman Wiranti dan Supriyadi \\ Program Studi Psikologi, Fakultas Kedokteran, Universitas Udayana \\ nwiranti@aol.com
}

\begin{abstract}
Abstrak
Menyusun skripsi merupakan salah satu area akademik yang penting sebagai salah satu syarat mahasiswa untuk mendapatkan gelar S1 (Catrunada, 2008). Pada proses pengerjaan skripsi, tidak sedikit mahasiswa yang mengalami kesulitan dan kegagalan, yang disebabkan oleh kecenderungan mahasiswa menunda-nunda mengerjakan skripsi. Dilihat dari faktor internal, efikasi diri adalah salah satu variabel yang terlibat dalam kelancaran skripsi mahasiswa. Sementara dari faktor eksternal, dukungan dosen pembimbing dinilai penting untuk kelancaran skripsi (Ratnawati, 2007). Penelitian ini bertujuan untuk mengetahui hubungan antara efikasi diri dan dukungan sosial dosen pembimbing terhadap prokrastinasi akadamik pada mahasiswa.
\end{abstract}

Responden dalam penelitian ini merupakan mahasiswa Universitas Udayana sebanyak 98 orang dengan metode pengambilan sampelnya yaitu simple random. Penelitian ini menggunakan validitas isi dan perhitungan reliabilitas Cronbach Alpha. Alat ukur yang digunakan adalah skala efikasi diri (18 aitem; rxx` = 0,780), skala dukungan sosial dosen pembimbing skripsi (22 aitem; rxx` $=0.929)$ dan skala prokrastinasi akademik (33 aitem; rxx` $=0.955)$.

Data diolah dengan analisis regresi linier ganda. Hasil penelitian menunjukkan terdapat hubungan antara efikasi diri dan dukungan sosial dosen pembimbing terhadap prokrastinasi akademik mahasiswa Universitas Udayana $(\mathrm{r}=$ 0,$695 ; \mathrm{p}=0,000$ ). Koefisien determinasi diperoleh sebesar 0,483 yang berarti sumbangan efektif dari variabel efikasi diri dan dukungan sosial dosen pembimbing terhadap variabel prokrastinasi akademik sebesar 48,3\%.

Kata kunci : efikasi diri, dukungan sosial, prokrastinasi akademik, mahasiswa

\begin{abstract}
Writing thesis is one of the important academic area as one of the requirements to earn a bachelor degree (Catrunada, 2008). In the process of writting thesis, a lot of student who have difficulties and failures are caused by the tendency of procrastination. Judging from internal factor, self-efficacy is one of the variables involved in the smoothness of university student's thesis. While from external factor, supervisor support is considered essential for the smoothness of university student's thesis (Ratnawati, 2007). This study aims to find the relationship between self-efficacy and supervisor social support toward academic procrastination.

Respondents in this study are a student at Udayana University as many as 98 students using simple random sampling as a sampling method. This study used content validity and reliability of Cronbach Alpha. Measured instruments used are the self-efficacy scale $\left(18\right.$ items; $\left.\mathrm{rxx}^{`}=0.780\right)$, supervisor social support scale $\left(22\right.$ items; $\left.\mathrm{rxx}^{`}=0.929\right)$ and academic procrastination scale (33 items; $\left.\mathrm{rxx}^{`}=0.955\right)$.

Data processed by multiple linear regression analysis. The results show there is a relationship between self-efficacy and supervisor social support toward Udayana University student academic procrastination $(\mathrm{r}=0.695, \mathrm{p}=0.000)$. The coefficient of determination obtained at 0.483 , which means the effective contribution of variables self-efficacy and social support to academic procrastination were $48.3 \%$.
\end{abstract}

Keywords: self-efficacy, social support, academic procrastination, university student 


\section{N.N. WIRANTI DAN SUPRIYADI}

\section{LATAR BELAKANG}

Mahasiswa pada dasarnya adalah kaum intelektual muda yang memiliki potensi untuk mengembangkan kemampuan penalaran individual guna mewujudkan tujuan tri dharma perguruan tinggi. Mahasiswa juga merupakan penerus dan pewaris tongkat estafet kepemimpinan bangsa dan negara kedepannya. Secara harfiah, tugas utama yang diemban oleh mahasiswa adalah belajar dan merangkai ilmu untuk memperoleh pengetahuan dan pemahaman setinggi-tingginya sesuai dengan tujuan ilmu agar menjadi rahmat bagi kehidupan (Ziaulhaq, 2011). Berbagai hal yang dipelajari oleh mahasiswa begitu kompleks, mulai dari alam semesta, kehidupan masyarakat, perilaku individu, perkembangan ekonomi, perkembangan teknologi dan perkembangan dunia.

Hal ini mengindikasikan bahwa mahasiswa tidak dapat lepas dari proses belajar. Proses belajar yang perlu untuk dilaksanakan secara baik dan benar agar dapat menghasilkan output yang unggul. Pada kenyataannya, dinamika yang terjadi pada kebanyakan mahasiswa tidaklah selalu merujuk pada pelaksanaan belajar yang baik dan benar. Terdapat sangat banyak permasalahan yang dihadapi mahasiswa seperti permasalahan ekonomi, kesulitan beradaptasi dengan perkuliahan, tuntutan organisasi mahasiswa dan beberapa hal lainnya (Zuliana, 2013).

Masalah yang umum dihadapi oleh mahasiswa biasanya bermunculan ketika mahasiswa telah sampai pada tahap penyusunan skripsi. Menyusun skripsi merupakan salah satu area akademik yang penting karena menjadi salah satu syarat mahasiswa untuk mendapatkan gelar Strata1/Sarjana (Catrunada, 2008). Biasanya kesulitan yang dihadapi dalam menyusun skripsi adalah banyak mahasiswa yang tidak terampil dalam tulis-menulis, adanya kemampuan akademis yang kurang memadai, serta kurangnya ketertarikan mahasiswa pada penelitian (Slamet, 2003). Kegagalan dalam penyusunan skripsi juga disebabkan oleh adanya kesulitan mahasiswa dalam mencari judul skripsi, kesulitan mencari literatur dan bahan bacaan, dana yang terbatas, serta adanya kecemasan dalam menghadapi dosen pembimbing (Riewanto, 2003). Kesulitan tersebut dapat menjadi permasalahan selama menyusun skripsi yang dapat juga menjadi alasan untuk menunda-nunda mengerjakan skripsi.

Permasalahan umum yang dihadapi mahasiswa Indonesia adalah menunda-nunda yang biasa dikenal dengan istilah prokrastinasi. Prokrastinasi merupakan hal yang sangat umum dan sering terjadi dalam setiap kegiatan manusia (Klassen, Krawchuk, \& Rajani, 2008). Mahasiswa kerap menemukan kesulitan untuk meraih nilai maksimal dalam perkuliahan yang dijalaninya, yang semata-mata bukan karena faktor kemampuan kognitif, memburuknya prestasi akademik mahasiswa bisa dipicu oleh faktor prokrastinasi dengan gejalanya antara lain perfeksionis, cemas terhadap penilaian, takut akan tugas, ketergantungan bantuan dan malas (Kompas.com, 2008).

Skripsi merupakan salah satu tugas makalah yang sering ditunda-tunda pengerjaannya oleh mahasiswa. Jangka waktu pengerjaan skripsi selama dua semester secara ideal dapat diselesaikan dalam satu semester (Yuwanto, 2013). Pada kenyataannya, banyak mahasiswa yang masih belum menyelesaikan skripsinya walau telah melewati dua semester. Tidak mengherankan apabila prokrastinasi dewasa ini telah menjadi gaya hidup di kalangan masyarakat, yang mana sekitar 20 persen masyarakat di dunia mengidentifikasikan dirinya sebagai pengidap kronis prokrastinasi, seperti tidak membayar tagihan tepat waktu, kehilangan kesempatan membeli sesuatu yang diinginkan, atau terlambat mengirimkan surat atau email (Candra, 2008).

Prokrastinasi akademik juga dapat mempengaruhi kualitas sebuah institusi pendidikan. Menjamurnya universitas-universitas di Indonesia selayaknya diiringi juga dengan kualitas yang mumpuni dari perguruan tinggi tersebut. Salah satu faktor yang menentukan kualitas perguruan tinggi adalah persentase kemampuan mahasiswa untuk menyelesaikan studi tepat waktu. Berdasarkan matriks penilaian instrumen akreditasi program studi Badan Akreditasi Nasional Perguruan Tinggi (BAN-PT), bahwa persentase mahasiswa yang lulus tepat waktu merupakan salah satu elemen penilaian akreditasi universitas (Hastuti, 2012). Pada tahun ajaran 2013/2014 dari Universitas Udayana sendiri, jumlah mahasiswa yang belum menyelesaikan studinya melewati batas empat tahun mencapai 498 mahasiswa (Pusat Komunikasi Universitas Udayana, 2014). Apabila persentasenya semakin meningkat, dikhawatirkan akan dapat menurunkan kualitas Universitas Udayana yang merupakan universitas negeri tertua di Bali.

Terdapat begitu banyak kerugian dan dampak negatif yang ditimbulkan karena perilaku prokrastinasi. Kesehatan adalah salah satunya, apabila dikaitkan dengan ranah akademis, mahasiswa pengidap prokrastinasi cenderung bermasalah dengan kekebalan tubuh, lebih sering terserang flu dan batuk, masalah pencernaan serta insomnia. Selain itu, prokrastinasi merugikan diri sendiri dan orang lain dengan cara mengalihkan beban tanggung jawab pada orang lain yang lalu menimbulkan perasaan menyesal. Prokrastinasi juga dapat merusak kekompakan tim di tempat kerja dan hubungan pribadi yang dijalin (Candra, 2008).

Disamping itu, pengaruh faktor internal dalam diri individu juga penting untuk ditelusuri. Salah satu faktor internal dalam diri individu adalah efikasi diri. Efikasi diri yang dimiliki individu dianggap sebagai indikator positif dalam keberhasilan kegiatan individu tersebut (Bandura, 1997). Adanya kesulitan-kesulitan dalam pengerjaan skripsi seperti yang telah disebutkan dan penundaan tugas terdapat dalam komponen efikasi diri itu sendiri. 
Skripsi diidentikkan sebagai tugas yang menekan dan menguras pikiran para mahasiswa. Biasanya pada saat menghadapi peristiwa-peristiwa yang menekan, seorang individu membutuhkan dukungan sosial (Cobb, 1976). Individu yang memiliki dukungan sosial yang tinggi tidak hanya mengalami stres yang rendah, tetapi juga dapat mengatasi stres secara lebih baik dibanding dengan individu yang kurang memperoleh dukungan sosial (Taylor, 1999). Pada tahap penyusunan skripsi mahasiswa difasilitasi oleh dosen pembimbing skripsi, yaitu akademisi yang bertugas untuk membimbing mahasiswa terkait untuk mengerjakan skripsinya hingga selesai.

Ada mahasiswa yang menilai bahwa dukungan dari dosen pembimbing penting untuk kelancaran skripsi yang dikerjakan (Ratnawati, 2007). Dukungan sosial tersebut seperti ketersediaan waktu untuk melakukan bimbingan yang cukup dan umpan balik terhadap tulisan mahasiswa. Tidak sedikit mahasiswa yang mempersepsikan dosen pembimbingnya tidak memberikan dukungan pada apa yang dibuat dengan berbagai alasan. Dalam keadaan mahasiswa mengalami persepsi yang demikian, maka keyakinan akan kemampuan diri mahasiswa cenderung menurun yang dapat berakibat pada prokrastinasi akademik.

Hal inilah yang melatarbelakangi penulis ingin mencari tahu lebih dalam apakah terdapat hubungan antara efikasi diri dan dukungan sosial dosen pembimbing pada perilaku prokrastinasi di kalangan mahasiswa, khususnya mahasiswa Universitas Udayana, sehingga dengan mengetahui hal tersebut lebih dalam diharapkan dapat memberikan kontribusi dan saran perbaikan untuk mahasiswa dan akademisi-akademisi yang berperan dalam proses bimbingan terhadap mahasiswa.

\section{Hipotesis Penelitian}

Terdapat hubungan negatif yang signifikan antara efikasi diri dan dukungan sosial dosen pembimbing dengan prokrastinasi akademik mahasiswa Universitas Udayana.

\section{Variabel dan definisi operasional}

Definisi operasional efikasi diri adalah persepsi atau keyakinan individu pada kemampuan dan kapabilitias dirinya sendiri dalam mengerjakan tugas-tugas perkuliahan seperti skripsi. Efikasi diri diukur menggunakan skala dengan bentuk skala Likert dan kuesioner yang disusun oleh peneliti. Aspekaspek efikasi diri terdiri dari tingkat (level), keluasan (generality) dan kekuatan (strength).

Definisi operasional dukungan sosial merupakan segala macam bantuan yang berasal dari luar diri individu (eksternal) untuk menunjang kenyamanan fisik maupun psikologis. Terkait dengan penelitian ini, dukungan sosial yang dimaksud adalah dukungan yang berasal dari satu atau dua orang yang merupakan dosen pembimbing skripsi yang mendampingi mahasiswa selama menempuh skripsinya. Variabel dukungan sosial dosen pembimbing skripsi akan diukur dengan skala dukungan sosial dosen pembimbing skripsi yang telah peneliti susun.

Definisi operasional prokrastinasi akademik yang dimaksud dalam penelitian ini adalah penundaan dalam ranah akademik yang terjadi pada mahasiswa, yaitu menunda-nunda pengerjaan skripsi. Aspek prokrastinasi akademik terdiri dari 1) Adanya penundaan dalam memulai menyelesaikan kinerja dalam menghadapi tugas, 2) Adanya kelambanan dalam mengerjakan tugas, 3) Adanya kesenjangan waktu antara rencana dengan kinerja aktual dalam mengerjakan tugas, dan 4) Adanya kecenderungan untuk melakukan aktivitas lain yang dipandang lebih mendatangkan hiburan dan kesenangan. Variabel ini akan diukur dengan skala prokrastinasi akademik yang telah peneliti susun.

\section{Karakteristik responden}

Populasi dalam penelitian ini adalah mahasiswa tingkat akhir yang masih aktif menempuh pendidikan di Universitas Udayana pada tahun ajaran 2014. Adapun mereka yang termasuk populasi adalah yang telah menempuh pendidikan lebih dari 4 tahun dan merupakan mahasiswa angkatan 2007, 2008 dan 2009. Total mahasiswa yang berada pada posisi tersebut berjumlah 498 orang. Jumlah sampel minimal dalam penelitian ini sebanyak 98 orang dengan menggunakan perhitungan jumlah sampel rumus Slovin dengan taraf kesalahan 0,10. Penelitian ini dilaksanakan di Universitas Udayana pada tanggal 4 Mei sampai dengan 2 Juni 2014.

\section{Teknik Pengambilan Sampel}

Sampel penelitian diambil dengan metode pengambilan sampel secara acak yaitu teknik random sampling yang mana memberikan peluang yang sama bagi setiap anggota populasi untuk dipilih menjadi anggota sampel (Creswell, 2009; Sugiyono, 2011). Sampel mahasiswa yang dipilih melalui proses pengundian secara acak, kemudian setelahnya akan dipilih kembali menyesuaikan kriteria inklusi yang ditetapkan.

\section{Alat Ukur}

Pada pengukuran variabel bebas, peneliti menggunakan skala efikasi diri yang dikembangkan berdasarkan aspek efikasi diri dari Bandura (1997) yaitu level, generality dan strength dan skala dukungan sosial dosen 
pembimbing skripsi dikembangkan berdasarkan aspek dukungan sosial dari Sarafino dan Smith (2011) yaitu, dukungan emosional, dukungan penghargaan, dukungan instrumental dan dukungan informasional. Format penilaian yang digunakan untuk mengungkap efikasi diri dan persepsi mahasiswa terkait dukungan sosial dosen pembimbing skripsi adalah dengan menggunakan skala Likert yang dimodifikasi menjadi empat alternatif jawaban, yaitu: sangat setuju (SS), setuju (S), tidak setuju (TS) dan sangat tidak setuju (STS). Nilai masing-masing jawaban pada skala sebagai item favorabel yaitu sangat setuju (SS) bernilai empat, setuju (S) bernilai tiga, tidak setuju (TS) bernilai dua, dan sangat tidak setuju (STS) bernilai satu. Item unfavorabel yaitu sangat setuju (SS) bernilai satu, setuju (S) bernilai dua, tidak setuju (TS) bernilai tiga dan sangat tidak setuju (STS) bernilai 4 empat.

Pada pengukuran variabel tergantung, peneliti menggunakan skala prokrastinasi akademik yang dikembangkan berdasarkan aspek prokrastinasi akademik dari Ferrari (2010) yaitu, 1) Adanya penundaan dalam memulai menyelesaikan kinerja dalam menghadapi tugas, 2) Adanya kelambanan dalam mengerjakan tugas, 3) Adanya kesenjangan waktu antara rencana dengan kinerja aktual dalam mengerjakan tugas, dan 4) Adanya kecenderungan untuk melakukan aktivitas lain yang dipandang lebih mendatangkan hiburan dan kesenangan. Format penilaian yang digunakan untuk mengungkap prokrastinasi akademik adalah dengan menggunakan skala Likert yang dimodifikasi menjadi empat alternatif jawaban, yaitu: sangat setuju (SS), setuju (S), tidak setuju (TS) dan sangat tidak setuju (STS). Nilai masingmasing jawaban pada skala sebagai item favorabel yaitu sangat setuju (SS) bernilai empat, setuju (S) bernilai tiga, tidak setuju (TS) bernilai dua, dan sangat tidak setuju (STS) bernilai satu. Item unfavorabel yaitu sangat setuju (SS) bernilai satu, setuju (S) bernilai dua, tidak setuju (TS) bernilai tiga, dan sangat tidak setuju (STS) bernilai 4 empat.

Pada penelitian ini terlebih dahulu dilakukan uji validitas dan reliabilitas terhadap skala pengukuran efikasi diri, dukungan sosial dosen pembimbing skripsi dan prokrastinasi akademik. Validitas dalam penelitian ini diuji dengan validitas isi (content validity). Pengujian validitas isi dilakukan dengan tryout isi dan bahasa. Pada tryout isi dan bahasa, peneliti melakukan pengecekan berulang terhadap instrumen penelitian bersama rekan-rekan sesama peneliti. Selanjutnya pengujian validitas isi dilanjutkan dengan expert judgement, pada bagian ini butir-butir pernyataan dalam instrumen penelitian dikonsultasikan dengan profesional yang kompeten pada bidang kajian yang diteliti sebagai acuan dasar penegakan validitas isi instrumen penelitian. Hal ini dilakukan untuk mengetahui layak atau masih harus disempurnakan kembali instrumen penelitian tersebut (Suryabrata, 2006). Kelayakan sebuah instrumen penelitian dapat dilihat dari kesesuaian blueprint dengan indikator dan aitem-aitemnya. Setelah expert judgment dari ahli selesai, diteruskan dengan uji coba instrumen. Instrumen yang telah disetujui para ahli tersebut dicobakan pada sampel dari mana populasi diambil. Jumlah anggota sampel yang digunakan minimal 30 orang (Sugiyono, 2011).

Secara empiris, uji kesahihan butir aitem pada penelitian ini dilakukan melalui pendekatan konsistensi internal dengan cara mengkorelasikan masing-masing skor aitem dengan skor total dan melakukan koreksi terhadap nilai koefisien korelasi yang melebihi sebenarnya (overestimation). Hal ini dinyatakan oleh koefisien korelasi aitem total dengan batas minimun rix $\geq 0,30$, batas ini dipilih berdasarkan pernyataan Cronbach (Azwar, 1997) bahwa koefisien validitas yang memuaskan berkisar antara 0,30 sampai 0,50. Menurut Azwar (1997) semua aitem yang mencapai koefisien korelasi minimal 0,30 daya pembedanya dianggap memuaskan. Apabila jumlah aitem yang lolos ternyata masih tidak mencukupi jumlah yang diinginkan, dapat dipertimbangkan untuk menurunkan sedikit batas kriteria menjadi 0,25 sehingga jumlah aitem yang diinginkan dapat tercapai (Azwar, 2012). Koefisien dengan nilai tersebut sudah dianggap mampu memberikan kontribusi yang baik.

Pengukuran reliabilitas instrumen pada penelitian ini menggunakan pendekatan Single Trial Administration yang menghasilkan estimasi reliabilitas konsistensi internal. Formula konsistensi internal yang digunakan adalah formula koefisien Cronbach Alpha (a), sebagaimana ditunjukkan oleh namanya, data untuk menghitung koefisien reliabilitas Alpha diperoleh lewat sekali saja penyajian skala pada sekelompok responden. Pada penelitian ini b $\neg$ atas koefisien reliabilitas Cronbach Alpha (a) minimal yang digunakan adalah 0,60 sesuai syarat minimal yang dikemukakan oleh Cronbach (Azwar, 2012).

Hasil uji kesahihan item pada skala efikasi diri melalui pengujian korelasi aitem total diperoleh koefisien korelasi aitem total yang bergerak dari -0.10 hingga 0,524 . Terdapat 24 aitem yang gugur dari 42 aitem yang diuji dan 18 aitem dinyatakan valid. Setelah aitem-aitem yang memiliki validitas rendah dieliminasi, validitas aitem meningkat bergerak dari 0,262-0,622.

Skala dukungan sosial dosen pembimbing skripsi juga melalui pengujian korelasi aitem total dengan nilai -0,348 hingga 0,512 . Terdapat 10 aitem yang gugur dari 32 aitem yang diuji dan 22 item dinyatakan valid. Setelah aitem-aitem yang memiliki validitas rendah dieliminasi, validitas aitem meningkat bergerak dari 0,394 hingga 0,884.

Pada skala prokrastinasi akademik, dari pengujian korelasi aitem total diperoleh koefisien korelasi aitem total yang bergerak dari -0,504 hingga 0,630. Terdapat 24 aitem yang gugur dari 42 aitem yang diuji dan 18 aitem dinyatakan valid. Setelah aitem-aitem yang memiliki validitas rendah 
dieliminasi, validitas aitem meningkat bergerak dari 0,305 hingga 0,790 .

Skala efikasi diri dalam penelitian ini memiliki nilai Alpha $(\alpha)$ sebesar 0,780 , hal ini menunjukkan bahwa skala ini mampu mencerminkan $78 \%$ variasi skor subjek adalah skor murni. Hasil tersebut menggambarkan bahwa skala ini dapat diandalkan, sehingga skala ini dapat digunakan untuk mengukur efikasi diri.

Skala dukungan sosial dosen pembimbing skripsi dihitung menggunakan penghitungan reliabilitas skor komposit. Dari hasil penghitungan dengan formula Mosier, didapatkan reliabilitas skala dukungan sosial dosen pembimbing skripsi sebesar 0,929. Hasil tersebut menggambarkan skala dukungan sosial dosen pembimbing skripsi mampu mencerminkan 92,9\% variasi skor subjek adalah skor murni, yang berarti skala ini dapat diandalkan untuk mengukur dukungan sosial dosen pembimbing skripsi.

Pada skala prokrastinasi akademik, peneliti juga menggunakan penghitungan reliabilitas skor komposit, yang dari hasil penghitungan formula Mosier didapatkan reliabilitas skala prokrastinasi akademik sebesar0,955. Hasil ini menggambarkan bahwa skala prokrastinasi akademik mampu mencerminkan $95,5 \%$ variasi skor subjek adalah skor murni sehingga skala ini dapat diandalkan untuk mengukur prokrastinasi akademik mahasiswa.

\section{Metode pengumpulan data}

Fink (2002) memaparkan empat strategi pengumpulan data, antara lain; 1) kuesioner yang disusun sendiri (self-administered questionnaires), 2) wawancara, 3) review catatan terstruktur (structured record review) untuk mengumpulkan informasi finansial, medis atau sekolah dan 4) observasi terstruktur (structured observation). Pada penelitian ini, peneliti menggunakan strategi pengumpulan data dengan skala yang disusun sendiri.

\section{Analisa data}

Penelitian ini menggunakan analisis statistik inferensial - parametrik menggunakan regresi berganda. Statistik inferensial $\mathrm{m}$ erupakan teknik statistik yang digunakan untuk menganalisis data sampel dan hasilnya diberlakukan untuk populasi dan bermaksud untuk membuat kesimpulan (Sugiyono, 2011). Analisis regresi berganda digunakan apabila bermaksud meramalkan keadaan variabel dependen bila dua atau lebih variabel independen sebagai prediktor dimanipulasi (Sugiyono, 2011). Analisis regresi berganda dipilih oleh peneliti karena variabel bebas yang dilibatkan dalam penelitian ini berjumlah lebih dari satu variabel, jenis data pada variabel bebas dan tergantung adalah interval dan sampel dipilih melalui metode acak.
Sebelum analisis regresi ganda dilakukan, terdapat syarat-syarat yang harus dipenuhi yakni dengan melakukan uji asumsi klasik berupa uji normalitas, uji linearitas dan uji multikolinearitas. Uji distribusi normal atau normalitas digunakan untuk mengetahui normal atau tidaknya sebaran skor antara variabel bebas dengan variabel tergantung. Data disebut berdistribusi normal apabila signifikansi lebih besar dari 0,05 (Pryatno, 2008). Uji linearitas dilakukan untuk mengetahui apakah dua variabel memiliki hubungan yang linear atau tidak secara signifikan. Uji ini digunakan sebagai prasyarat dalam analisis regresi. Uji ini dilakukan dengan menggunakan Test for Linearity Compare Means dengan taraf signifikansi 0,05. Sedangkan uji multikolinieritas betujuan untuk menguji apabila pada model regresi ditemukan adanya korelasi antar variabel bebas. Model regresi yang baik seharusnya tidak terdapat korelasi di antara variabel bebas (Ghozali, 2005). Dikatakan terjadi multikolinieritas apabila nilai tolerance $<0,10$ atau sama dengan nilai $\mathrm{VIF}>10$ (Ghozali, 2005). Ketiga uji tersebut dilakukan melalui Statistical Package for Social Science (SPSS) versi 17 for windows.

Uji hipotesis dalam penelitian ini menggunakan taraf signifikansi sebesar 0.01 atau 0,05 yang artinya apabila nilai signifikansi probabilitas kurang dari 0,01, maka variabel bebas dan variabel tergantung memiliki hubungan yang signifikan dan variabel bebas secara signifikan mempengaruhi variabel tergantung. Ketepatan fungsi regresi dapat dinilai dari Goodness of Fit, yang secara statistik diukur dari nilai statistik F, nilai statistik t dan nilai koefisien determinasi (Ghozali, 2005).

\section{HASIL PENELITIAN}

Setelah melaksanakan uji coba skala penelitian, peneliti kemudian melakukan proses pengambilan sampel dengan cara memilih subjek-subjek dalam daftar data populasi secara acak. Dari proses tersebut, didapatkan 120 orang subjek terpilih untuk mengisi skala penelitian. 120 orang subjek yang tepilih tidak berasal dari subjek yang telah menjadi sampel uji coba. Penelitian ini dilaksanakan sejak tanggal 4 Mei 2014 sampai dengan 2 Juni 2014. Populasi penelitian ini adalah mahasiswa universitas Udayana angkatan 2007, 2008 dan 2009 yang masih tercatat sebagai mahasiswa aktif pada tahun 2014. Subjek penelitian di spesifikkan pada mahasiswa yang sedang mengerjakan skripsi.

Sebelum melaksanakan penelitian, peneliti meminta ijin dengan menyampaikan surat pengantar pelaksanaan penelitian kepada Biro Administrasi Akademik Universitas Udayana. Peneliti menyebar 120 skala yang dibagikan pada 120 mahasiswa yang tersebar dari 11 fakultas di Universitas Udayana yakni, Fakultas Kedokteran, Kedokteran Hewan, Sastra, Teknologi Pertanian, Teknik, Ekonomi \& Bisnis, 


\section{EFIKASI DIRI DAN DUKUNGAN SOSIAL DOSEN PEMBIMBING SKRIPSI PADA PROKRASTINASI AKADEMIK MAHASISWA}

Matematika dan Ilmu Pengetahuan Alam (MIPA), Peternakan, Pertanian, Ilmu Sosial \& Politik dan dari Fakultas Hukum. Jumlah skala yang kembali pada akhir pengumpulan adalah 104 skala, namun hanya 98 skala yang memenuhi syarat kelengkapan untuk dapat digunakan dalam analisis data. Tabel 1, tabel 2 dan tabel 3 akan merangkum karakteristik subjek penelitian ini.

Tabel 1.

Deskripsi Subjek Penelitian Berdasarkan Fakultas

\begin{tabular}{lcc}
\hline \multicolumn{1}{c}{ Fakultas } & Jumlah Mahasiswa & Persentase (\%) \\
\hline Kedokteran & 3 orang & $3,06 \%$ \\
Kedokteran Hewan & 5 orang & $5,10 \%$ \\
Sastra & 3 orang & $3,07 \%$ \\
Teknologi Pertanian & 5 orang & $5,10 \%$ \\
Teknik & 30 orang & $30,61 \%$ \\
Ekonomi \& Bisnis & 8 orang & $8,16 \%$ \\
MIPA & 18 orang & $18,36 \%$ \\
Peternakan & 2 orang & $2,04 \%$ \\
Pertanian & 16 orang & $16,32 \%$ \\
Tlmu Sosial \& Politik & 2 orang & $2,04 \%$ \\
Hukum & 6 orang & $6,12 \%$ \\
\hline
\end{tabular}

Tabel 2.

Deskripsi Subjek Penelitian Berdasarkan Angkatan

\begin{tabular}{ccc}
\hline Angkatan & Jumlah Mahasiswa & Persentase (\%) \\
\hline 2007 & 17 orang & $17,34 \%$ \\
2008 & 25 orang & $25,51 \%$ \\
2009 & 56 orang & $57,14 \%$ \\
\hline
\end{tabular}

Tabel 3.

Deskripsi Subjek Penelitian Berdasarkan jenis Kelamin

\begin{tabular}{ccc}
\hline Jenis Kelamin & Jumlah Mahasiswa & Persentase (\%) \\
\hline Laki-laki & 65 orang & $66,32 \%$ \\
Perempuan & 33 orang & $33,68 \%$ \\
\hline
\end{tabular}

Pada penelitian ini peneliti melakukan tiga kategorisasi skor skala penelitian, yaitu kategorisasi dari skala efikasi diri, skala dukungan sosial dosen pembimbing skripsi dan kategorisasi prokrastinasi akademik yang dikategorisasikan dalam lima golongan. Tujuan dari penggolongan ini adalah untuk menempatkan subjek ke dalam kelompok yang terpisah secara berjenjang menurut kontinum berdasarkan atribut yang diukur (Azwar, 2012). Kategorisasi skala efikasi diri, dukungan sosial dosen pembimbing skripsi dan kategorisasi skala prokrastinasi akademik dapat dilihat pada tabel 4, tabel 5 dan tabel 6 .

Tabel 4.

Kategorisasi Subjek pada Skala Efikasi Diri

\begin{tabular}{|c|c|c|c|c|}
\hline Variabel & Rentang Nilai & Kategori & Subyek & Persentase \\
\hline \multirow{5}{*}{$\begin{array}{c}\text { Efikasi } \\
\text { diri }\end{array}$} & $\mathrm{X} \leq 31,5$ & Sangat Rendah & 0 orang & $0 \%$ \\
\hline & $31,5-40,5$ & Rendah & 7 orang & $7,14 \%$ \\
\hline & $40,5-49,5$ & Sedang & 52 orang & $53,06 \%$ \\
\hline & $49,5-58,5$ & Tinggi & 28 orang & $28,57 \%$ \\
\hline & $58.5<\mathrm{X}$ & Sangat Tinggi & 11 orang & $11,23 \%$ \\
\hline
\end{tabular}

Kategorisasi pada skala efikasi diri menunjukkan bahwa tidak ada subjek yang termasuk dalam kategori sangat rendah, kategori rendah ada $7,14 \%$ (7 orang), kategori sedang ada $53,06 \%$ (52 orang), kategori tinggi ada $28,57 \%$ (28 orang) dan sebanyak 11,23\% (11 orang) masuk kategori sangat tinggi.

Tabel 5.

\begin{tabular}{|c|c|c|c|c|}
\hline Variabel & Rentang Nilai & Kategori & Subyek & Persentase \\
\hline Dukungan & $\mathrm{X} \leq 38,5$ & Sangat Rendah & 2 orang & $2,04 \%$ \\
\hline Sosial & $38,5-49,5$ & Rendah & 8 orang & $8,16 \%$ \\
\hline Dosen & $49,5-60,5$ & Sedang & 22 orang & $22,45 \%$ \\
\hline Pembimbing & $60,5-71,5$ & Tinggi & 51 orang & $52,04 \%$ \\
\hline Skripsi & $71,5<x$ & Sangat Tinggi & 15 orang & $15,30 \%$ \\
\hline
\end{tabular}

Kategorisasi pada skala dukungan sosial dosen pembimbing skripsi menunjukkan bahwa subjek yang termasuk dalam kategori sangat rendah hanya ada 2,04\% (2 orang), kategori rendah ada $8,16 \%$ (8 orang), kategori sedang ada $22,45 \%$ (22 orang), kategori tinggi ada 52,04\% (51 orang) dan kategori sangat tinggi sebanyak 15,30\% (15 orang).

Tabel 6.

Kategorisasi Subjek pada Skala Prokrastinasi Akademik

\begin{tabular}{ccccc}
\hline Variabel & Rentang Nilai & Kategori & Subyek & Persentase \\
\hline & $\mathrm{X} \leq 57,75$ & Sangat Rendah & 5 orang & $5,10 \%$ \\
Prokrastinasi & $57,75-74,25$ & Rendah & 22 orang & $22,45 \%$ \\
Akademik & $74,25-90,75$ & Sedang & 55 orang & $56,12 \%$ \\
& $90,75-107,25$ & Tinggi & 17 orang & $17,34 \%$ \\
& $107,25<\mathrm{X}$ & Sangat Tinggi & 0 orang & $0 \%$ \\
\hline & Jumlah & & 98 orang & $100 \%$ \\
\hline
\end{tabular}

Kategorisasi pada skala prokrastinasi akademik menunjukkan subjek yang termasuk dalam kategori sangat rendah hanya ada $5,10 \%$ (5 orang), kategori rendah ada $22,45 \%$ (22 orang), kategori sedang ada 56,12\% (55 orang) dan kategori tinggi sebanyak 17,34\% (17 orang).

Pengujian hipotesis mula-mula diawali dengan melakukan uji asumsi terlebih dahulu. Uji asumsi pertama yang harus terpenuhi dalam penelitian ini adalah uji normalitas. Sebaran data pada variabel efikasi diri memiliki nilai signifikansi (p) 0,097 atau mempunyai probabilitas kesalahan di atas 0,05 (p > $0,05)$. Hal ini menunjukkan bahwa sebaran data pada variabel efikasi diri bersifat normal. Sebaran data pada variabel dukungan sosial dosen pembimbing skripsi memiliki nilai signifikansi (p) 0,183 atau mempunyai probabilitas kesalahan di atas 0,05 ( $p>0,05)$. Hal ini menunjukkan bahwa sebaran data pada variabel dukungan sosial dosen pembimbing skripsi bersifat normal. Sebaran data pada variabel prokrastinasi akademik memiliki nilai signifikansi (p) 0,150 atau mempunyai probabilitas kesalahan di atas 0,05 ( $p>0,05)$. Hal ini menunjukkan bahwa sebaran data pada variabel prokrastinasi akademik bersifat normal.

Uji asumsi kedua yang harus terpenuhi dalam penelitian ini adalah uji linieritas. Hasil uji menunjukkan 
bahwa hubungan efikasi diri, dukungan sosial dosen pembimbing skripsi dan prokrastinasi akademik adalah linier karena memiliki taraf signifikansi untuk linearitas lebih kecil dari $0,05(\mathrm{p}<0,05)$ sehingga dikatakan bahwa skor variabel efikasi diri, dukungan sosial dosen pembimbing skripsi dan prokrastinasi akademik memiliki hubungan yang linier.

Uji asumsi berikutnya yang harus terpenuhi adalah uji multikolinieritas. Hasil pengujian menunjukkan bahwa nilai tolerance sebesar 0,673 $(>0,10)$ dan nilai VIF (variance inflation factor) sebesar $1,487 \quad(<10)$, sehingga dapat dikatakan tidak terdapat multikoliniearitas antar variabel bebas efikasi diri dan dukungan sosial dosen pembimbing skripsi. Berdasarkan uji normalitas, linieritas dan multikolinieritas yang telah dilakukan, diperoleh hasil bahwa data penelitian bersifat normal, linier dan tidak terdapat multikolinieritas, sehingga analisis regresi ganda dapat dilanjutkan.

Tabel 7.

Hasil Uji Signifikansi Simultan Garis Regresi

\begin{tabular}{|c|c|c|c|c|c|c|}
\hline \multicolumn{7}{|c|}{ ANOVA $^{\mathrm{a}}$} \\
\hline & Model & $\begin{array}{c}\text { Sum of } \\
\text { Squares }\end{array}$ & $\mathrm{Df}$ & Mean Square & $\mathrm{F}$ & Sig. \\
\hline \multirow{3}{*}{1} & Regression & 8050.726 & 2 & 4025.363 & 44.442 & $.000^{\mathrm{b}}$ \\
\hline & Residual & 8604.621 & 95 & 90.575 & & \\
\hline & Total & 16655.347 & 97 & & & \\
\hline
\end{tabular}

a. Dependent Variabel : Academic Procrastination

b. Predictors(Constant): Social Support, Self-efficacy

Pengujian hipotesis dalam penelitian ini menggunakan uji hipotesis satu ekor (one tailed). Berdasarkan komputasi statistik pada tabel 7 didapatkan nilai probabilitas (p) pada taraf signifikansi $1 \%$ sebesar 0,000 (p < 0,01). Probabilitas kesalahan yang lebih kecil dari 0,01 ini juga memberi arti bahwa model regresi dapat dipercaya meramalkan kontribusi variabel bebas yaitu efikasi diri dan dukungan sosial dosen pembimbing skripsi dalam memprediksi variabel tergantung yaitu prokrastinasi akademik.

\section{Tabel 8.}

Hasil Uji Regresi Parameter Individual

\begin{tabular}{|c|c|c|c|c|c|c|c|c|}
\hline \multirow{2}{*}{\multicolumn{2}{|c|}{ Model }} & \multicolumn{2}{|c|}{$\begin{array}{c}\text { Unstandardized } \\
\text { Coefficients }\end{array}$} & \multirow{2}{*}{$\begin{array}{c}\text { Standardized } \\
\text { Coefficients } \\
\text { Beta }\end{array}$} & \multirow[b]{2}{*}{$\mathrm{t}$} & \multirow{2}{*}{ Sig. } & \multicolumn{2}{|c|}{$\begin{array}{l}99.0 \% \text { Confidence } \\
\text { Interval for B }\end{array}$} \\
\hline & & B & $\begin{array}{l}\text { Std. } \\
\text { Error }\end{array}$ & & & & $\begin{array}{l}\text { Lower } \\
\text { Bound }\end{array}$ & $\begin{array}{l}\text { Upper } \\
\text { Bound }\end{array}$ \\
\hline \multirow{3}{*}{1} & (Constant) & 151.225 & 7.644 & & 19.785 & .000 & 131.133 & 171.317 \\
\hline & Self-efficacy & -1.030 & .176 & -.526 & -5.850 & .000 & -1.493 & -567 \\
\hline & Social Support & -.331 & .122 & -.244 & -2.716 & .008 & -650 & -011 \\
\hline
\end{tabular}

Tabel 8 menunjukan seberapa jauh pengaruh variabel bebas secara individual dalam menerangkan variasi variabel tergantung. Melalui tabel ini juga dapat dilihat arah hubungan yang terjadi dan apakah hubungan yang terjadi merupakan hubungan yang bersifat sebab-akibat (Ghozali, 2012).

Arah hubungan efikasi diri dengan prokrastinasi akademik dapat dilihat dari nilai koefisien regresi (B). Pada tabel 8, nilai $\mathrm{B}$ bertanda negatif $(\mathrm{B}=-1,030)$. Tanda negatif $(-)$ berarti bahwa variabel bebas dan variabel tergantung memiliki hubungan yang berkebalikan. Semakin tinggi efikasi diri, maka tingkat prokrastinasi akademik akan semakin rendah. Begitu pula sebaliknya, apabila semakin rendah efikasi diri, maka tingkat prokrastinasi akademik akan semakin tinggi.

Nilai probabilitas (p) pada taraf signifikansi $1 \%$ yang terdapat pada tabel 8 uji signifikansi menunjukkan angka 0,000 ( $\mathrm{p}$ $0,01)$, artinya efikasi diri memiliki hubungan yang signifikan dengan prokrastinasi akademik, yang berarti hubungan efikasi diri dengan gejala prokrastinasi akademik dapat diduga sebagai suatu gejala sebab-akibat. Hubungan ini diyakini sebagai gejala sebab-akibat dan dapat diramalkan apabila terjadi kenaikan 1 nilai pada variabel efikasi diri maka nilai prokrastinasi akademik akan turun sebesar 0,331. Hal ini diketahui dari fungsi persamaan garis regresi $\mathrm{Y}=\mathrm{a}+\mathrm{bX}$ untuk variabel efikasi diri dan prokrastinasi akademik yaitu $\mathrm{Y}$ $=151,225+(-1,030) \mathrm{X}$.

Arah hubungan dukungan sosial dosen pembimbing skripsi dengan prokrastinasi akademik juga dapat dilihat dari nilai koefisien regresi (B). Pada tabel 8, nilai B bertanda negatif (B $=-0,331)$. Tanda negatif $(-)$ berarti bahwa variabel bebas dan variabel terikat memiliki hubungan yang berkebalikan. Semakin tinggi dukungan sosial dosen pembimbing skripsi maka tingkat prokrastinasi akademik akan semakin rendah. Begitu pula sebaliknya, apabila semakin rendah dukungan sosial dosen pembimbing skripsi maka tingkat prokrastinasi akademik akan semakin tinggi.

Nilai probabilitas (p) pada taraf signifikansi $1 \%$ yang terdapat pada tabel uji t menunjukkan angka 0,008 (p < 0,01), artinya dukungan sosial dosen pembimbing skripsi memiliki hubungan yang signifikan dengan prokrastinasi akademik, yang mana hubungan dukungan sosial dosen pembimbing skripsi dengan gejala prokrastinasi akademik dapat diduga sebagai suatu gejala sebab-akibat. Hubungan ini diyakini dapat diramalkan apabila terjadi kenaikan 1 nilai pada variabel dukungan sosial dosen pembimbing skripsi, maka nilai prokrastinasi akademik akan turun sebesar 0,331 . Hal ini dapat diketahui dari fungsi persamaan garis regresi $\mathrm{Y}=\mathrm{a}+\mathrm{bX}$ untuk variabel efikasi diri dan prokrastinasi akademik, yaitu $\mathrm{Y}$ $=151,225+(-0,331) \mathrm{X}$.

Keterangan :

$\mathrm{Y}=$ nilai subjek dalam variabel tergantung yang diprediksikan $\mathrm{a}=$ harga konstan atau nilai $\mathrm{Y}$ (variabel tergantung) bila $\mathrm{X}$ (variabel bebas) adalah 0

$\mathrm{b}=$ angka arah atau koefisien regresi, yang menunjukkan angka peningkatan ataupun penurunan variabel tergantung yang didasarkan pada variabel bebas

$\mathrm{X}=$ nilai subjek pada variabel bebas

Tabel 9.

Hasil Sumbangan Efektif Variabel Efikasi Diri dan Dukungan Sosial Dosen Pembimbing Skripsi terhadap Variabel Prokrastinasi Akademik

\begin{tabular}{lrrrr}
\hline Model & $\mathrm{R}$ & $\mathrm{R}$ Square & $\begin{array}{c}\text { Adjusted } \mathrm{R} \\
\text { Square }\end{array}$ & $\begin{array}{c}\text { Std. Error of the } \\
\text { Estimate }\end{array}$ \\
\hline 1 & $.695^{\mathrm{a}}$ & .483 & .472 & 9.517 \\
\hline a. Predictors: (Constant), Efikasi diri, dukungan sosial dosen pembimbing skripsi &
\end{tabular}


Pada tabel 9 dapat diketahui sumbangan variabel bebas terhadap variabel tergantung melalui analisis regresi yang diperoleh dari koefisien determinasi (R2) dengan mengkuadratkan nilai koefisien korelasi $(r=0,695)$ sehingga didapatkan hasil R2 sebesar 0,483. Berdasarkan koefisien determinasi sebesar 0,483, diperoleh sumbangan efektif dari variabel efikasi diri dan dukungan sosial dosen pembimbing skripsi terhadap variabel prokrastinasi akademik sebesar $48,3 \%$.

\section{PEMBAHASAN DAN KESIMPULAN}

Penelitian ini telah berhasil membuktikan hipotesis yang berbunyi, "terdapat hubungan negatif yang signifikan antara efikasi diri dan dukungan sosial dosen pembimbing skripsi terhadap prokrastinasi akademik mahasiswa universitas Udayana". Hipotesis tersebut dapat diterima berdasarkan hasil analisis statistik regresi ganda yang telah dilakukan.

Hasil uji signifikansi simultan dari analisis regresi yang dilakukan menunjukkan signifikansi sebesar $0,000(\mathrm{p}<$ $0,01)$ yang berarti, garis regresi dapat dipercaya untuk meramalkan variabel tergantung yakni prokrastinasi akademik dari variabel bebas yakni efikasi diri dan dukungan sosial dosen pembimbing skripsi. Koefisien regresi (B) bernilai negatif ( $\mathrm{B}=-1,030$ dan $-0,331$ ) yang memiliki makna bahwa kedua variabel bebas saling berkolerasi negatif atau berlawanan arah, yang berarti jika terjadi peningkatan nilai pada variabel efikasi diri dan dukungan sosial dosen pembimbing skripsi, maka akan terjadi penurunan nilai pada variabel prokrastinasi akademik. Begitu pun sebaliknya, jika terjadi penurunan nilai pada variabel efikasi diri dan dukungan sosial dosen pembimbing skripsi, makan akan terjadi peningkatan nilai pada variabel prokrastinasi akademik.

Nilai koefisien korelasi (r) dalam penelitian ini adalah 0,695. Mengacu pada interpretasi koefisien korelasi Sugiyono (2011) yang terdapat pada tabel 10, diketahui bahwa nilai koefisien korelasi 0,695 berada pada kategori hubungan yang kuat. Tingkat hubungan yang kuat ini berada pada interval $0,60-0,799$.

Tabel 10.

Interpretasi Nilai Koefisien Korelasi (r) menurut Sugiyono (2011)

\begin{tabular}{cc}
\hline Interval Koefisien & Tingkat Hubungan \\
\hline $0,00-0,199$ & Sangat rendah \\
$0,20-0,399$ & Rendah \\
$0,40-0,599$ & Sedang \\
$0,60-0,799$ & Kuat \\
$0,80-1,000$ & Sangat kuat \\
\hline
\end{tabular}

Penerimaan hipotesis ini menunjukkan bahwa prokrastinasi akademik yang dialami mahasiswa tingkat akhir universitas Udayana memiliki hubungan yang signifikan dengan efikasi diri dan dukungan sosial yang mereka persepsikan dari dosen pembimbing skripsi saat mengerjakan skripsi.
Besaran kontribusi variabel efikasi diri dan dukungan sosial dosen pembimbing skripsi dapat dilihat melalui nilai koefisien determinasi (r2) yang menunjukkan angka 0,483 yang berarti bahwa variabel efikasi diri dan dukungan sosial dosen pembimbing skripsi dapat memprediksi atau memberikan sumbangsih sebesar $48,3 \%$ pada terjadinya prokrastinasi akademik di kalangan mahasiswa tingkat akhir Universitas Udayana. Sisanya, sebanyak 51,7\% dipengaruhi oleh faktor lain di luar variabel efikasi diri dan dukungan sosial dosen pembimbing skripsi.

Mengerjakan skripsi kerap menjadi tugas yang paling banyak dihindari oleh mahasiswa, meskipun sebetulnya skripsi merupakan tugas akhir yang mutlak harus diselesaikan untuk meraih gelar sarjana. Bagi sebagian orang, skripsi dianggap pekerjaan yang sangat berat dan menakutkan. Kesulitan yang sering ditemui seperti, teknik penulisan, penguasaan bahasa Indonesia, kurangnya membaca, tidak terbiasa menulis, sulitnya mencari literatur dan bahan bacaan, dana yang terbatas dan takut menemui dosen pembimbing skripsi pada akhirnya menyebabkan stres, frustasi, kehilangan motivasi, menunda penyusunan skripsi dan bahkan ada yang memutuskan untuk tidak menyelesaikan skripsinya (Catrunada, 2008).

Kehilangan motivasi sama halnya dengan kehilangan kepercayaan diri akan kemampuan menyelesaikan pekerjaan di ranah akademik. Mahasiswa yang memiliki motivasi yang tinggi dalam menulis skripsi akan menunjukkan performa yang tekun untuk mendapatkan hasil yang baik (Lestari, 2012). Semakin tinggi efikasi diri akan menopang motivasi dan meningkatkan pengembangan keterampilan akademik (Schunk, 1991). Di sisi lain, efikasi diri sangat penting bagi pelajar untuk mengontrol motivasi mencapai harapan-harapan akademik karena menjadi penentu suksesnya perilaku akademik di masa yang akan datang. Salah satu penelitian eksperimen yang pernah dilakukan juga menunjukkan bahwa mereka yang diberikan latihan berpikir positif untuk meningkatkan efikasi diri memiliki motivasi yang lebih besar daripada kelompok kontrol yang tidak diberikan (Dwitantyanov, Hidayati, \& Sawitri, 2010).

Banyak faktor yang dapat mempengaruhi motivasi mahasiswa antara lain, kurang tersedia alat yang memadai, lingkungan mahasiswa yang berada, harapan terhadap dosen pembimbing skripsinya dan kemampuan yang dimiliki oleh dosen (Lestari, 2012). Selain motivasi, dukungan sosial dosen pembimbing skripsi juga terbukti berkontribusi dan berhubungan dengan prokrastinasi akademik mahasiswa. Peran dosen pembimbing skripsi sangat besar terhadap kelancaran skripsi mahasiswa karena bertugas mendampingi mahasiswa dalam menyelesaikan skripsinya. Oleh karenanya mahasiswa perlu dukungan dari dosen pembimbing skripsinya. Dukungan sosial dapat meningkatkan kepercayaan diri mahasiswa dalam mempersiapkan bahan-bahan studinya 
karena interaksinya dengan dosen dianggap dapat memberikannya pengetahuan baru dan nilai-nilai lebih untuk mengerjakan tugas berat. Apabila sedari awal mahasiswa telah mempersepsikan dosennya tidak mendukung, maka akan diikuti dengan tindakan acuh yang menyebabkan dukungan yang rendah pula dari fakultas tempatnya bernaung (Namaste, 2007).

Pada deskripsi data penelitian, variabel efikasi diri dan dukungan sosial dosen pembimbing skripsi memiliki nilai mean empiris yang lebih besar daripada mean teoretisnya. Sedangkan pada variabel prokrastinasi akademik, nilai mean empiris lebih kecil daripada mean teoretis. Artinya, bentuk hubungan yang diperoleh adalah semakin tinggi efikasi diri dan dukungan sosial dosen pembimbing skripsi, semakin rendah prokrastinasi pada mahasiswa Universitas Udayana.

Apabila ditinjau dari data demografi, subjek penelitian berasal dari angkatan 2007, 2008 dan 2009 namun belum menyelesaikan studinya di tahun ajaran 2014. Diduga manajemen diri adalah salah satu faktor yang mempengaruhi, hal tersebut dapat terjadi karena mahasiswa tidak dapat mengatur waktu dengan baik dan sulit untuk fokus karena aktivitas lain seperti, bekerja dan aktif berorganisasi di kampus (Triana, 2013). Menurut Lakein (dalam Triana, 2013) manajemen diri pertama kali dimulai dengan menentukan apa yang sebenarnya menjadi kebutuhan dan keinginan individu berdasarkan tingkat kepentingannya, kemudian membuat prioritas aktivitas yang spesifik agar dapat dicapai. Ketika bekerja, mahasiswa mengalami pengurangan waktu yang lebih banyak untuk mengerjakan dan menyelesaikan tugas-tugas akademiknya daripada mahasiswa lain pada umumnya, sehingga mereka harus memiliki kemampuan dalam mengelola diri untuk dapat menyelesaikan tugas akademiknya dengan tepat waktu. Selain itu, tidak efektifnya komunikasi antara dosen pembimbing skripsi dengan mahasiswa juga mempengaruhi terjadinya penundaan skripsi. Menurut Gunawati (2005) tidak adanya titik temu antara dosen pembimbing skripsi dengan mahasiswa perihal jalan keluar skripsi membuat mahasiswa lamban dalam menyelesaikan skripsi. Kendatipun mahasiswa telah berusaha dan rajin melakukan bimbingan, namun apabila karya yang dibuat belum memenuhi standar yang diminta oleh dosen pembimbing skripsi, maka mahasiswa harus memperbaiki kembali karyanya.

Hal tersebut membuat mahasiswa enggan untuk bimbingan. Riset yang dilakukan Novita Anggi Lestari (2012) di Universitas Negeri Semarang menunjukkan bahwa mahasiswa yang merasa tidak diberikan umpan balik positif oleh dosen pembimbing skripsinya ditandai dengan gejala malas mengerjakan skripsi, jarang terlihat dikampus dan tidak melakukan bimbingan dalam jangka waktu yang lama, kendatipun mahasiswa tersebut tidak mempunyai kesibukan diluar kampus. Hasil ini didapat dari wawancara terhadap 37 mahasiswa Unnes, yang mana 89,19\% mahasiswa enggan mengerjakan skripsinya.

Berdasarkan deskripsi data demografi subjek, didapat data tambahan setelah dilakukannya analisis sebagai berikut. Ditinjau dari perbedaan jenis kelamin, dari 98 orang responden penelitian, $66,32 \%$ berjenis kelamin laki-laki dan $33,68 \%$ responden berjenis kelamin perempuan. Peneliti melakukan analisis tambahan yakni uji komparasi statistk parametrik dengan menggunakan teknik Independent Sample t-Test untuk mengetahui perbedaan efikasi diri, dukungan sosial dosen pembimbing skripsi dan prokrastinasi akademik antara laki-laki dan perempuan. Hasilnya, tidak terdapat perbedaan efikasi diri berdasarkan jenis kelamin yang ditunjukkan dengan skor probabilitas sebesar 0,158 ( $p>0,05)$. Tidak adanya perbedaan mungkin terjadi karena jumlah sampel yang tidak terlalu banyak sehingga diversitas subjek tidak terlalu signifikan.

Berikutnya adalah tidak ada perbedaan persepsi dukungan sosial dosen pembimbing skripsi berdasarkan jenis kelamin yang diuji menggunakan Independent Sample t-Test. Uji komparasi yang sama dilakukan dan menunjukkan skor probabilitas $0,114(\mathrm{p}>0,05)$.

Selanjutnya tidak ada perbedaan prokrastinasi akademik berdasar jenis kelamin yang diuji dengan teknik Independent Sample t-Test. Uji komparasi yang sama dilakukan dan menunjukkan skor probabilitas 0,617 ( $\mathrm{p}>0,05)$. Menurut Akmal (2013), mahasiswa perempuan cenderung memiliki tingkat rerata prokrastinasi lebih rendah daripada laki-laki. Hal ini disebabkan ketika mahasiswa laki-laki melakukan penundaan, mereka akan menunjukkan respon santai, lebih bersikap tenang dibanding mahasiswa perempuan dan sangat jarang mahasiswa laki-laki memperhatikan suasana hatinya. Kebanyakan mahasiswa laki-laki lebih menikmati penundaan dengan mengalihkan ke pekerjaan lain, terlibat dalam aktivitas yang lebih menyenangkan dan cenderung mengarah pada sikap negatif seperti mengabaikan tugas akademiknya. Berbeda dengan mahasiswa laki-laki, mahasiswa perempuan ketika melakukan prokrastinasi cenderung bersikap menyalahkan diri sendiri, menyesali keadaan dan sebagainya, sehingga mahasiswa perempuan masih memiliki keinginan dan usaha yang lebih tinggi untuk menyelesaikan tugas akademiknya.

Kendati demikian, terdapat penelitian lain yang membahas bahwa terdapat perbedaan prokrastinasi akademik antara laki-laki dan perempuan. Perbedaan antara laki-laki dan perempuan selain sebagai perbedaan fisiologis, juga dibahas sebagai perbedaan gender. Gender melekat pada kaum lakilaki maupun perempuan baik secara sosial maupun kultural. Gender merujuk pada segala sesuatu yang berhubungan dengan jenis kelamin termasuk peran, tingkah laku, kecenderungan dan atribut lain. Secara psikologis, usia 
kematangan perempuan lebih awal dibandingkan laki-laki (Hurlock, 2002).

Dilihat dari asal fakultas, tiga besar responden terbanyak berasal dari fakultas teknik yaitu sebanyak 30,61\% disusul fakultas MIPA sebanyak 18,36\% dan 16,32\% berasal dari fakultas pertanian. Peneliti berasumsi, banyaknya sebaran responden mahasiswa akhir pada ketiga fakultas tersebut dikarenakan kompleksitas perkuliahan yang mereka dapatkan. Mereka yang berada pada Fakultas Teknik, MIPA dan pertanian lebih banyak mempelajari ilmu eksakta dibandingkan dengan ilmu sosial, yang mana bagi sebagian orang stereotype yang melekat selama ini adalah mempelajari ilmu eksakta lebih sulit daripada mempelajari ilmu sosial dan mendapat nilai baik pada ilmu sosial lebih mudah daripada ilmu eksakta. Diungkapkan oleh Rila salah satu mahasiswa Teknik UGM (dalam Dian, 2014) yang melihat temantemannya yang belajar di ilmu sosial jadwal kuliahnya lebih santai dan lebih mudah menjalani perkuliahannya. Streotype seperti ini melekat pada setiap jurusan Teknik dan fakultas yang mayoritas mempelajari ilmu eksakta sehingga terjadi prokrastinasi yang tinggi pada fakultas tersebut.

Persepsi efikasi diri yang tinggi merepresentasikan perasaan optimis pada kompetensi pribadi yang dimiliki seorang individu yang dapat meningkatkan motivasi dan pencapaian individu dalam dalam kehidupannya sehari-hari (Scholz, Donna, Sud, \& Schawrzer, 2002). Tingginya efikasi diri yang dimiliki oleh mahasiswa Universitas Udayana perlu untuk dipertahankan dan dijaga sebaik-baiknya. Mempertahankan efikasi diri dapat dilakukan dengan menerapkan self-regulated learning yakni proses pembelajaran yang dilakukan individu dengan menetapkan standard dan tujuan yang ditetapkan sendiri.

Prokrastinasi akademik memang menjadi perilaku yang umum dialami mahasiswa universitas. Riset juga menunjukkan bahwa prokrastinasi dapat mengarah pada berbagai masalah psikologis seperti kecemasan dan depresi walaupun probabilitasnya tidak terlalu tinggi (Klassen, Krawchuk, \& Rajani, 2008). Sehingga mahasiswa tetap perlu mewaspadai agar intensitas prokrastinasi yang dialami dapat ditekan. Menerapkan self-regulated learning dalam kehidupan sehari-hari dapat membantu mahasiswa mengurangi perilaku prokrastinasi akademik. Individu yang memiliki selfregulation tinggi akan efektif dalam penggunaan waktu, selalu hadir dalam perkuliahan, serta mereduksi kelambanan. Menurut Ghufron (2004), dengan adanya self-regulation mahasiswa mampu menampilkan serangkaian tindakan yang ditujukan untuk pencapaian target dengan melakukan perencanaan terarah, sehingga prokrastinasi dapat diminimalisir. Riset lainnya juga menunjukkan bahwa mahasiswa yang memiliki self-regulation yang tinggi mengalami prokrastinasi yang lebih rendah daripada mahasiswa lainnya (Wolters, 2003). Itulah mengapa self- regulation menjadi kunci penting sehingga individu dapat mengatur waktu dan dirinya, dengan demikian prokrastinasi akademik dapat diminimalisir.

Berdasarkan penelitian yang telah dilakukan, hasilnya dapat disimpulkan bahwa terdapat hubungan negative pada efikasi diri dan dukungan sosial dosen pembimbing skripsi dengan prokrastinasi akademik mahasiswa Universitas Udayana. Hubungan yang terjadi antara variabel efikasi diri dan dukungan sosial dosen pembimbing skripsi terhadap variabel prokrastinasi akademik adalah hubungan yang kuat dengan nilai koefisien korelasi (r) sebesar 0,695 dan hubungannya dapat dipercaya sebagai hubungan kausal atau bukan gejala acak/random. Sumbangan efektif yang dapat diberikan efikasi diri dan dukungan sosial dosen pembimbing skripsi terhadap prokrastinasi akademik adalah sebesar 48,3\%.

Saran praktis yang dapat dipertimbangkan berdasarkan hasil penelitian ini kepada para mahasiswa agar meningkatkan intensitas bimbingan dengan dosen pembimbing skripsi. Mahasiswa diharapkan untuk mendiskusikan jadwal bimbingan dengan dosen pembimbing skripsinya. Jadwal yang dimaksud adalah pertemuan reguler yang berkelanjutan minimal 1 minggu sekali. Kebanyakan mahasiswa yang menunda skripsinya biasanya disebabkan karena tidak intens bimbingan. Mahasiswa juga sebaiknya menjalin komunikasi yang positif dan efektif dengan dosen pembimbing skripsi. Mahasiswa sebaiknya bersikap terbuka dengan dosen pembimbing skripsi agar terjalin komunikasi yang positif dan efektif. Hal ini dapat terwujud dalam tindakan seperti menanyakan bahasan yang tidak dipahami, meminjam literatur yang tidak dimiliki dan mendiskusikan kesulitan penelitian. Sehingga akan memunculkan titik temu antara dosen pembimbing skripsi dan mahasiswa mengenai jalan keluar penyelesaian skripsi.

Bagian yang terakhir, mahasiswa diharapkan melatih manajemen diri yang baik. Mahasiswa sebaiknya meletakkan penyelesaian skripsi sebagai tingkat prioritas kepentingan yang ingin dicapai. Dengan manajemen diri yang baik, mahasiswa dapat memilih prioritas yang sebaiknya didahulukan kendatipun mahasiswa sudah bekerja.

Saran praktis bagi penelitian selanjutnya diharapkan untuk menambah jumlah sampel, sampel dapat dijaring dari berbagai jenjang angkatan agar mendapatkan lebih banyak sampel. Penelitian serupa juga dapat dilakukan di universitas lain di Indonesia agar dapat memberikan gambaran hasil dari latar belakang universitas yang berbeda. Sumbangan efektif dalam penelitian ini sebesar 48,3\% sedangkan sisanya sebanyak $51,7 \%$ dijelaskan oleh faktor lain. Faktor-faktor lain yang tidak diteliti dalam penelitian ini seperti, motivasi, selfcontrol dan self-regulated behavior dapat jadi bahan penelitian selanjutnya yang mungkin memiliki hubungan dan mempengaruhi prokrastinasi akademik, kemudian yang terakhir, peneliti selanjutnya dapat memperkaya data 
demografi dari subjek seperti melihat asal responden, latar belakang keluarga dan responden yang bekerja atau tidak bekerja, dengan dianalisis secara statistik kuantitatif atau analisis kualitatif.

\section{DAFTAR PUSTAKA}

Akmal, V. E. (2013). Perbedaan prokrastinasi akademik berdasarkan jenis kelamin dengan mengontrol manajemen waktu pada mahasiswa yang kuliah sambil bekerja di yogyakarta [electronic version]. Jurnal Fakultas Psikologi Universitas Ahmad Dahlan.

Asy'ari, S. I. (1983). Metode Penelitian Sosial. Surabaya: Usaha Nasional.

Azwar, S. (1997). Reliabilitas dan Validitas. Yogyakarta: Pustaka Pelajar.

Azwar, S. (2012). Penyusunan Skala Psikologi Edisi II. Yogyakarta: Pustaka Pelajar.

Bandura, A. (1997). Self-Efficacy: The Exercise of Control. New York: W.H. Freeman and Company.

Bernard, M. (1991). Procrastinate Later! How to Motivate Yourself to Do It Now. Australia: Schwartz \& Wilkinson.

Boorom, M. L., Goolsby, J. R., \& Ramsey, R. P. (1998). Relational communication traits and their effect on adaptiveness and sales performance [electronic version]. Journal of Academy of Marketing Science Vol. 26, 16-30.

Candra, A. (2008). Awas terjerat prokrastinasi! [electronic version]. Diakses

November11,2013,fromhealth.kompas.com:http://health.ko mpas.com/read/2008/03/26/10112191/Awas.Terjerat.Prokr astinasi

Catrunada, L. (2008). Perbedaan kecenderungan prokrastinasi tugas skripsi berdasarkan tipe kepribadian introvert dan ekstrovert. Tesis. Jakarta: Universitas Gunadarma.

Chu, A., \& Choi, J. (2005). Rethinking procrastionation: positive effects of "active" procrastination behavior on attitudes and performance [electronic version]. Journal of Social Psychology, 245-264.

Clegg, S., \& Bailey, J. (2008). Procrastination. in international encyclopedia of organizational studies vol 4 (pp. 13061308) [electronic version]. Thousand Oaks, CA: SAGE Publications.

Cobb, S. (1976). Social support as a moderator of life stress. Psychosomatic Medicine Vol. 38, no. 5, 300-314
Creswell, J. W. (2009). Research Design: Pendekatan Kualitatif, Kuantitatif dan Mixed Edisi Ketiga. Yogyakarta: Pustaka Pelajar.

Demeter, D. V., \& Davis, S. E. (2013). Procrastination as a tool: exploring unconventional components of academic success [electronic version]. Creative Education Vol. 4, 144-149.

Dian, R. (2014) Kuliah di jurusan sosial lebih ramah nilai. Diakses Juni 23, 2014, from Careeer Issue: http://careernews.web.id/issues/view/2365-Kuliah-diJurusan-Sosial-Lebih-Ramah-Nilai

Dwitantyanov, A., Hidayati, F., \& Sawitri, R. D. (2010). Pengaruh pelatihan berpikir positif pada efikasi diri akademik mahasiswa (studi eksperimen pada mahasiswa psikologi undip semarang) [electronic version]. Jurnal Psikologi Undip.

Feldman, R. S. (2003). Essentials of understanding psychology 5th Edition. New York: McGraw-Hill Higher Education.

Ferrari, J. (2010). Still Procrastinating? The No-Regrets Guide to Getting It Done. New Jersey: John Wiley \& Sons, Inc.

Fink, A. (2002). The Survey Kit: How to Design Surveys 2nd Edition. United States: Sage Publication.

Ghozali, I. (2005). Aplikasi Analisis Multivariate dengan Program SPSS. Semarang: Badan Penerbit Universitas Diponegoro.

Ghufron, N. M. (2004). Hubungan kontrol diri dan persepsi remaja terhadap penerapan disiplin orang tua dengan prokrastinasi akademik. Jurnal Psikologi Tabularasa, 1-18.

Gunawati, R. (2005). Hubungan antara efektivitas komunikasi mahasiswa-dosen pembimbing utama skripsi dengan stres dalam menyusun skripsi pada mahasiswa program studi psikologi fakultas kedokteran universitas diponegoro. Tesis. Semarang: Universitas Diponegoro.

Hastuti, K. (2012, Juni 23). Analisis komparasi algoritma klasifikasi data mining untuk prediksi mahasiswa non aktif. Seminar Nasional Teknologi Informasi \& Komunikasi Terapan, pp. 241-249.

Hen, M. (2012). Academic procrastination, emotional intelligence, academic self-efficacy and gpa: a comparison between student with and without learning disabilities [electronic version]. Eurasian Journal of Social Sciences , 1-10.

Husetiya, Y. (2010). Hubungan asetivitas dengan prokrastinasi akademik pada mahasiswa fakultas psikologi universitas diponegoro semarang. Skripsi. Semarang: Fakultas Psikologi Universitas Diponegoro. 


\section{EFIKASI DIRI DAN DUKUNGAN SOSIAL DOSEN PEMBIMBING SKRIPSI PADA PROKRASTINASI AKADEMIK MAHASISWA}

Janssen, T., \& Carton , J. (1999). The effect of locus of control and task difficulty on procrastination [electronic version]. Journal of Genetic Psychology 160, 436-442.

Kalechstein, P., Hocevar, D., Zimmer, J., \& Kalechstein, M. (1989). Procrastination over test preparation and test anxiety [electronic version]. Advances In Test Anxiety Research.

Klassen, R., Krawchuk, L., \& Rajani, S. (2008). Academic procrastination of undergraduates: low self-efficacy to selfregulate predicts higher levels of procrastination [electronic version]. Contemporary Educational Psychology, 915-931.

Knack, J., Waldrip, A., \& Jensen-Campbell, L. (2007). Social support. In R. F. Baumeister, \& D. Kathleen, Encyclopedia of Social Psychology Vol 2 (pp. 920-924). Thousand Oaks, CA: SAGE Publications.

Kompas.com. (2008). Itb bakal berlakukan sistem akademis ketat. Diakses

November11,2013,fromregional.kompas.com:http://regiona 1.kompas.com/read/2008/01/24/19342238/ITB.Bakal.Berla kukan.Sistem.Akademis.Ketat

Lee, E. (2005). The relationship of motivation and flow experience to academic procrastination in university students [electronic version]. The Journal of Genetic Psychology, 5-14.

Lestari, N. A. (2012). Hubungan ekspektasi terhadap dosen pembimbing dengan motivasi menulis skripsi [electronic version]. Education Psychology Journal I, 1-8.

Lunenburg, F. (2011). Self-efficacy in the workplace: implications for motivation and performance [electronic version]. International Journal Of Management, Business, And Administration Vol. 14, 1-6.

Messer, L. C. (2008). Self-efficacy. in e. s. boslaugh, Encyclopedia of Epidemiology. Vol. 2 (pp. 945-946). Thousand Oaks, CA: Sage Publications.

Muninjaya, A. G. (2003). Langkah-langkah Praktis Penyusunan Proposal dan Publikasi Ilmiah. Jakarta: EGC.

Namaste, P. R. (2007). Social Support in Doctoral Education: The Role of Relationship Resources and Gender in Graduate Student Profesional Socialization. Indiana: Indiana University.

O J, A. (2011). Influence of personality types and academic procrastination on the academic achievements of senior secondary school adolescents in ibadan metropolis [electronic version]. Ife Psychologia.

Odaci, H. (2011). Academic self-efficacy and academic procrastination as predictor of problematic internet use in university students. Journal of Computers and Education.
Onwuegbuzie, A. (2004). Academic procrastination and statistics anxiety. Assessment \& Evaluation in Higher Education Vol. 29, 1-18.

Orford, J. (1992). Community Psychology: Theory \& Practice. London: Wiley and Sons Inc.

Priyatno, D. (2008). Paham Analisis Statistik Data Dengan SPSS. Yogyakarta: Mediakom.

Program Studi Psikologi Fakultas Kedokteran Universitas Udayana. (2012). Buku Pedoman Penyusunan Skripsi. Denpasar: Universitas Udayana.

Orford, J. (1992). Community Psychology: Theory \& Practice. London: Wiley and Sons Inc.

Patrzek, J., Grunschel, C., \& Fries, S. (2012). Academic procrastination: the perspective of university counsellors. International Journal of Advanced Counselling, 185-201.

Ratnawati, I. (2007). Pendapat mahasiswa jurusan seni dan desain tentang profil dosen pembimbing skripsi yang dapat membantu penyelesaian skripsi. Bahasa dan Seni, Tahun 35, Nomor 2, 222-230.

Rausa, B. (2008). Social support. In M. Sajatovic, \& S. Loue, Encyclopedia of Aging and Public Health (pp. 751-754). New York: Springer.

Riewanto, A. (2003). Skripsi barometer intelektualitas mahasiswa. Diakses

Desember2,2013, fromsuaramerdeka.com:http://www.suara merdeka.com/harian/0302/05/kha3.htm

Santosa, S. (2003). SPSS Mengolah Data Statistik Secara Profesional. Jakarta: PT. Elex Media Komputindo.

Sarafino, E., \& Smith, T. (2011). Health psychology: biopsychosocial interactions 7th edition. United States: John Wiley \& Sons Inc.

Schaefer, R. T. (2008). Social support. In Encyclopedia of Race, Ethnicity, and Society Vol. 3 (pp. 1256-1258). Thousand Oaks, CA: SAGE Publications.

Scholz, U., Donna, G., Sud, S., \& Schawrzer, R. (2002). Is general self-efficacy a universal construct. European Journal of Psychological Assesment, 242-251.

Schunk, D. (1991). Self-efficacy and academic motivation. Educational Psychologist, 207-231.

Slamet. (2003). Banyak yang melakukan plagiat. Diakses Desember 2, 2013, from suaramerdeka.com: http://www.suaramerdeka.com/harian/0301/15/kha2.htm 
Solomon, L., \& Rothblum, E. (1984). Academic procrastination: frequency and cognitive behavior correlates. Journal of Counseling in Psychology, 503-509.

Sugiyono. (2011). Statistika Untuk Penelitian. Bandung: Alfabeta.

Sunyoto, D. (2009). Analisis Regresi dan Uji Hipotesis. Yogyakarta: Media Pressindo.

Suryabrata, S. (2006). Psikologi Pendidikan. Jakarta: PT. Raja Grafindo Persada.

Tatan, Z. (2012). Analisis prokrastinasi tugas akhir/skripsi. Prosiding Seminar Nasional Matematika dan Pendidikan Matematika, 92.

Triana, K. A. (2013). Hubungan antara orientasi masa depan dengan prokrastinasi dalam menyusun skripsi pada mahasiswa fakultas ilmu sosial dan ilmu politik (fisipol) universitas mulawarman samarinda. eJournal Psikologi Universitas Mulawarman, 280-291.

Tschannen-Moran, M., \& Hoy, W. A. (2007). The differential antecedents of self-efficacy beliefs. Elsevier: Teaching and Teacher Education, 944-956.

Udayana, P. K. (2014, April 13). Data Mahasiswa Tahun Ajaran 2013/2014. Denpasar, Bali, Indonesia.

Wolters, C. (2003). Understanding procrastination from a selfregulated learning perspective. Journal of Educational Psychology 95, 179-187.

Yuwanto, L. (2013). Mahasiswa prokrastinasi, mahasiswa dan dosen terbebani. Diakses November 11, 2013, from ubaya.ac.id: http://www.ubaya.ac.id/2013/content/articles_detail/79/Ma hasiswa-Prokrastinasi--Mahasiswa-dan-Dosen-

Terbebani.html

Ziaulhaq. (2011). Membangun karakter politik yang santun dan bermartabat. Medan: Fakultas Syariah IAIN SU .

Zuliana, B. (2013). Permasalahan mahasiswa. Diakses September 1, 2014 ,

fromsuaramerdeka.com:http://citizennews.suaramerdeka.co $\mathrm{m} /$ ?option=com_content\&task=view\&id=1921 